\title{
Larvicidal Activity of Beauveria bassiana Extracts against Aedes aegypti and Identification of Beauvericins
}

\author{
Juliana F. S. Daniel, ${ }^{*}, a$ Andressa A. Silva, ${ }^{a}$ Danielle H. Nakagawa, ${ }^{a}$ \\ Lívia S. de Medeiros, ${ }^{b}$ Mário G. Carvalho, ${ }^{c}$ Lucineli J. Tavares, ${ }^{c}$ Lucas M. Abreu ${ }^{d}$ and \\ Edson Rodrigues-Filho ${ }^{b}$
}

${ }^{a}$ Departamento de Química, Universidade Tecnológica Federal do Paraná (UTFPR), Avenida dos Pioneiros, 3131, 86036-370 Londrina-PR, Brazil

${ }^{b}$ Departamento de Química, Universidade Federal de São Carlos (UFSCar), CP 676, 13565-905 São Carlos-SP, Brazil

'Departamento de Química, ICE, Universidade Federal Rural do Rio de Janeiro (UFRRJ), Rodovia BR 465, Km 7, 23890-000 Seropédica-RJ, Brazil

${ }^{d}$ Departamento de Fitopatologia, Universidade Federal de Viçosa (UFV), 36570-000 Viçosa-MG, Brazil

\begin{abstract}
Beauveria bassiana is an entomopathogenic fungus that has been well known for its capacity to act as biopesticide on various disease vectors. The analysis of organic extracts of strains CG71 and UNI40 led to identification of cyclodepsipeptides beauvericin, beauvericin A or F, beauvericin $\mathrm{E}$ and bassianolide by ultra-high pressure liquid chromatography-high resolution mass spectrometry in tandem mode (UHPLC-HRMS/MS). The larvicidal activity on $3^{\text {rd }}$ instar of Aedes aegypti revealed $\mathrm{LC}_{50} 0.9887$ and $0.4653 \mathrm{ppm}$ in 24 and 48 hours (CG71 methanolic extract), $\mathrm{LC}_{50} 0.7834$ ppm in 48 hours (CG71 ethyl acetate), LC $_{50} 0.7834$ and 1.8149 ppm (UNI 40 for ethyl acetate and methanolic extracts, respectively) in 48 hours. These findings highlight the potential of $B$. bassiana metabolites for controlling the vector of Dengue and Zika diseases.
\end{abstract}

Keywords: cyclohexadepsipeptides, Dengue, Zika, beauvericins, UHPLC-HRMS/MS

\section{Introduction}

The entomopathogenic Beauveria bassiana has a broad host range naturally attacking insects and variety of arthropod species..$^{1-3}$ Due to this ability, it is used as a biopesticide agent on diverse disease vectors, including crop pests, ticks and mosquitoes. ${ }^{4,5}$ The attack on insect cuticle occurs after hyphae of $B$. bassiana penetrate the insect integument by enzymatic action. ${ }^{6}$

Species of entomopathogenic fungi have been described as producers of secondary metabolites, including bioactive non-ribosomal peptides and polyketides. ${ }^{7}$ B. bassiana produces the cyclooligomer nonribosomal depsipeptides beauvericins and bassianolide,${ }^{8,9}$ beauveriolides, ${ }^{10}$ tenellin, bassianin, ${ }^{11}$ pyridovericin, pyridomacrolidin, ${ }^{12}$ oosporein ${ }^{13}$ and bassiacridin. ${ }^{14}$

In special, beauvericin is an ionophoric cyclodepsipeptide

*e-mail: julianasouza@utfpr.edu.br detected in several fungi, mainly Beauveria, Paecilomyces and Fusarium species. ${ }^{15-17}$ It forms complexes with cations, causing an increase in permeability of natural and artificial membranes. ${ }^{18,19}$ Furthermore, beauvericin induces programmed cell death similar to apoptosis. ${ }^{20}$ Initially it was regarded as a toxin against brine shrimp, ${ }^{8}$ also showing insecticidal and antibiotic activities. ${ }^{21-23}$ It contains three residues each D-2-hydroxyisovaleric acid (Hiv) and $\mathrm{L}-N$-methylphenylalanine linked alternately.

Recently, new analogues of beauvericin were described, including beauvericin $\mathrm{A}, \mathrm{B},{ }^{24} \mathrm{D}, \mathrm{E}$ and $\mathrm{F}^{25}$ Bassianolide is another cyclooctadepsipeptide metabolite produced B. bassiana and Lecanicillium lecanii. ${ }^{9}$ It is toxic to insects and probably also acts as an ionophore, such as other cyclodepsipeptides. ${ }^{15}$ The structural diversity of metabolites from entomopathogenic fungi, associated with diverse biological activities, stimulates the research by on bioactive fungal extracts for controlling insect pests and disease vectors. 
Dengue is a viral infection transmitted to humans by Aedes aegypti mosquitoes that became a major concern of the public health sector. ${ }^{26}$ There were 96 million apparent dengue infections globally in 2010, of which the Americas contributed $14 \%$ (13 million infections) of worldwide and over half developed in Brazil and Mexico. ${ }^{27}$ Due to no effective antiviral agents and licensed vaccine for infection, the decrease in transmission depends only on vector control by elimination of artificial and disposable water inundated larvae breeding sites and application of insecticides. ${ }^{27,28}$ Furthermore, studies reveal resistance in the vector population to various substances, in Brazil there is an irregular distribution of insecticide resistance..$^{28}$

Furthermore, Aedes mosquitoes also transmit Zika virus; attracting worldwide attention in 2016, when the vector caused widespread epidemic cases in Brazil. ${ }^{29}$ This disease has been recognized in Brazil since late 2014, but in 2015 coincided with an increase in the number of cases of microcephaly. The more affected Brazilian states were Bahia, Paraíba, and Pernambuco, where in the first trimester of pregnancy coincided with reports of cases of febrile and allergy compatible with Zika virus disease, suggesting an association between Zika virus infection during early pregnancy and the occurrence of microcephaly. ${ }^{30}$

Consequently, there is an urgent need to develop new methods for A. aegypti mosquitoes infections control. So, fungal extracts are an alternative because they constitute a rich source of bioactive metabolites.

The paper reports the activity of two strains of Beauveria bassiana extracts on mortality of Aedes aegypti larvae and identification of beauvericins and bassianolide using ultra-high pressure liquid chromatography-high resolution mass spectrometry in tandem mode (UHPLC-HRMS/MS). Additionally, the fragmentation data of beauvericin $\mathrm{E}$ and A of $\mathrm{F}$ is provided.

\section{Experimental}

\section{Origin and preservation of $B$. bassiana}

The entomopathogenic fungal strains $B$. bassiana CG 71 and UNI 40 were kindly provided by Prof Dr Luis Francisco Angeli Alves from Universidade Estadual do Oeste do Paraná (Cascavel, PR, Brazil) and Prof Dr Pedro Manuel Oliveira Janeiro Neves from Universidade Estadual de Londrina (Londrina, PR, Brazil), respectively. The CG 71 and UNI 40 strains are preserved in the culture collection of Universidade Estadual do Oeste do Paraná and Universidade Estadual de Londrina, respectively. ${ }^{31}$ Both strains are also preserved at $-80{ }^{\circ} \mathrm{C}$ in the Coleção Micológica de Lavras, Universidade Federal de Lavras
(Lavras, MG, Brazil) under the accession numbers CML 2677 (CG 71) and CML 2678 (UNI 40).

\section{Morphological characterization}

The strains were preliminary identified as Beauveria bassiana based on the macro and micromorphological characteristics of colonies, conidia and conidiophores after cultivation for 7 days at room temperature on malt extract agar (Himedia, Mumbai, India). ${ }^{32}$

\section{DNA sequencing and phylogenetic analyses}

Strains CG 71 and UNI 40 were cultivated on malt extract agar for five days at $24{ }^{\circ} \mathrm{C}$. The mycelium was scrapped from the colonies, macerated under liquid nitrogen, and subjected to genomic DNA extraction with the Wizard Genomic Deoxyribonucleic Acid (DNA) Purification Kit (Promega, Madison, USA). A fragment of the second largest subunit of the ribonucleic acid (RNA) polymerase gene (RPB2) was amplified from the extracted DNA using the primers $5 \mathrm{~F}$ and $7 \mathrm{cR}$, and the polymerase chain reaction (PCR) conditions of Liu et al..$^{33}$ The purified PCR products were sent for DNA sequencing by a commercial service.

Consensus sequences were assembled using SeqAssem ver. 07/2008 (SequentiX - Digital DNA Processing, Germany). Blast searches against the GenBank database suggested that both strains belonged to Beauveria bassiana. DNA sequences of RPB2 from reference strains of Beauveria bassiana and related taxa ${ }^{34}$ were used to compose a multiple sequence alignment using multiple sequence comparison by log-expectation (MUSCLE), as implemented by Mega 6 software. ${ }^{35}$ Maximum likelihood (ML) phylogenetic analysis was conducted using Mega 6. 1000 bootstrap pseudo-replicates were employed for estimating node support. The general time reversible model with gamma distribution of rates across sites $(\mathrm{GTR}+\mathrm{G})$ model of evolution, estimated using JModeltest,$^{36}$ was used in the ML analysis. Isaria farinosa (ARSEF 4029) was used as the outgroup.

Culture of B. bassiana, extraction and chromatographic fractionation

The B. bassiana CG71 and UNI 40 strains were cultivated on potato dextrose agar (PDA) at $26{ }^{\circ} \mathrm{C}$ for 7 days, and pre-inoculated in $60 \mathrm{~mL}$ of supplemented liquid medium (ML) divided into 4 Erlenmeyer flasks $(50 \mathrm{~mL})$ containing $30.0 \mathrm{~g}$ glucose; $20.0 \mathrm{~g}$ malt extract; $2.0 \mathrm{~g}$ bactopeptone; $1.0 \mathrm{~g}$ yeast extract; $0.5 \mathrm{~g} \mathrm{KCl}$; 
$0.5 \mathrm{~g} \mathrm{MgSO}_{4} .7 \mathrm{H}_{2} \mathrm{O} ; 0.5 \mathrm{~g} \mathrm{KH}_{2} \mathrm{PO}_{4} ; 1 \mathrm{~L}$ water, as reported by Bunyapaiboonsri et al..$^{37}$ The flasks were incubated on a rotary shaker (200 rpm) for 8 days. These seed cultures ( $240 \mathrm{~mL}$ of each strain) were used to inoculate 11 liters ML (55 Erlenmeyer flasks of $1 \mathrm{~L}$ with $200 \mathrm{~mL}$ of medium for each strain). After incubation at room temperature for 20 days in static mode, the mycelium was separated by reduced pressure filtration and the liquid phase was submitted to liquid-liquid fractionation with ethyl acetate (EtOAc). After lyophilization, the mycelial masses were combined and extracted totally with methanol (MeOH). The organic solvents were removed by vacuum distillation at 55 and $60^{\circ} \mathrm{C}$ using a rotary evaporator.

The ethyl acetate extracts CG71a (4.7600 g) and UNI40a (4.9623 g), and the methanolic extracts CG71m $(18.8054 \mathrm{~g})$ and UNI40m (14.6802 g) were fractionated through Sephadex LH-20 (1.75 mm × $0.3 \varnothing)$ using $\mathrm{MeOH}$ as eluent. In both extracts of CG71 and UNI40 and some fractions were detected beauvericin, beauvericin A or F, beauvericin $\mathrm{E}$ and bassianolide.

\section{Cyclodepsipeptides identification}

The UHPLC-HRMS/MS analyzes were performed on an Accela High Speed LC coupled to a LTQ Orbitrap Velos FT-MS (ThermoFisher Scientific, San Jose, CA, USA), equipped with an electrospray source (HESI-II) and operated at a resolution of 60,000 FWHM, with positive ionization and $25 \mathrm{eV}$ at HRMS/MS mode. The chromatographic system was fitted with an $\mathrm{RP}$ Luna $\mathrm{C}_{18}$ column $(150 \times 4.6 \mathrm{~mm}, 5 \mu \mathrm{m}$, Phenomenex $)$ applying as mobile phase $\mathrm{H}_{2} \mathrm{O} / \mathrm{CH}_{3} \mathrm{OH}(30: 70 \rightarrow 0: 100$, v/v, both buffered with $0.1 \%$ of formic acid) in $15 \mathrm{~min}$ at a flow rate of $0.4 \mathrm{~mL} \mathrm{~min}{ }^{-1}$. The software Thermo Xcalibur 2.1 (ThermoFisher Scientific) was used to control the full system. The sample injection (auto injector) volume was $0.5 \mu \mathrm{L}$.

Bioassay to control Aedes aegypti larvae Rockefeller strain

The bioassay was performed at the Laboratory of Biocontrol of Arthropods (LABIART), Veterinary Institute, Department of Animal Parasitology, Universidade Federal Rural do Rio de Janeiro (UFRRJ). The extracts tested were CG71a, CG71m, UNI40a and UNI40m.

Aedes aegypti of the Rockefeller strain were maintained in colonies at $27 \pm 3{ }^{\circ} \mathrm{C}$, and $80 \%$ humidity on a 12-h light/ dark cycle. Four replications of ten (10) third instar larvae (L-3) of Aedes aegypti susceptible in the insecticide were tested in five concentrations: $25,50100,150$, and $200 \mu \mathrm{L}$ of each extract dissolved in dimethyl sulfoxide 10\% (DMSO).
Two control groups were tested, one containing the solvent used in extracts and the other containing only pure water. The analyzes of the results of larval mortality were assessed at 15 minutes and at successive counts of 15,30 minutes, $1,2,3$ and 24 and 48 hours. The lethal concentrations $\mathrm{LC}_{50}$ and their respective confidence intervals were calculated through Probit analyses, using the R software (R Core Team).

\section{Results and Discussion}

The ethyl acetate and methanol extracts of entomopathogenic fungi Beauveria bassiana UNI40 and CG71 were analyzed by HRMS data analysis, obtained in an Orbitrap mass analyzer. The metabolites beauvericin (1), beauvericin A (2) or F (2a), beauvericin E (3) and bassianolide (4) were identified (Figure 1).

\section{Cyclodepsipeptides fragmentation}

Mass spectrometry has played essential role in the structure determination of cyclodepsipeptides originated from diverse fungal species, grains and foods. The fragmentation is a main step in sequencing and primary stage usually is bond rupture in the ester or amide group..$^{38}$ Interpretation and elucidation of the amino acid sequence using collision-induced dissociation (CID) depends essentially on the sequence of specific ions present $\left(a_{n}, b_{n}\right.$, $c_{n}$ and $\left.x_{n}, y_{n}, z_{n}\right)$. The fragment ions produced in this process can be divided in two series. ${ }^{39}$

Beauvericin is a cyclohexadepsipeptide isolated in 1969 from B. bassiana, derived from two dipeptidol monomers alternately, D-hydroxyisovalerate (D-HiV) and $\mathrm{N}$-methyl-L-phenylalanine (N-Me-Phe), while bassianolide isolated in 1977 from B. bassiana and Verticillium lecanii is a cyclooctadepsipeptide also formed by two dipeptidol monomers units of D-hydroxyisovalerate (D-HiV) and $\mathrm{N}$-methyl-L-leucine (N-Me-Leu). ${ }^{18}$

The cyclodepsipeptides beauvericin, beauvericin A or F, beauvericin $\mathrm{E}$ and bassianolide were detected in two strains of B. bassiana (CG71 and UNI 40) extracts and fractions semi-purified according to the observed accurate masses for protonated molecule and the corresponding cationized molecules, displayed at their full scan spectra (Figure 2) and selected ion chromatogram (Figure 3). Moreover, the product ion spectra allowed the comparison of the compounds fragmentation profile to the data found in the literature (Table 1).24,25,40-44

The electrospray ionization tandem mass spectra (ESI-MS/MS) and fragmentation mechanism proposal for beauvericin A or F are depicted in Figures 4 and 5, 
<smiles>[R]C(OC(=O)C(Cc1ccccc1)N(C)C(=O)C(OC(=O)C(Cc1ccccc1)N(C)C(=O)C(OC(=O)C([R])N(C)C(=O)C(C)C)C(C)C)C(C)C)C(=O)O</smiles><smiles>CC(C)CC(C(=O)OC(C(=O)N(C)C(CC(C)C)C(=O)O)C(=O)N(C)C(CC(C)C)C(=O)OC(C(=O)N(C)C(CC(C)C)C(=O)N(C)C(OC(=O)C(CC(C)C)C(C)C)C(C)C)C(C)C)C(C)C</smiles><smiles>[R][R]#CCCc1ccccc1CCC[R]</smiles>

\section{4}

Figure 1. Structures of compounds 1-4 identified from the extracts of B. bassiana.
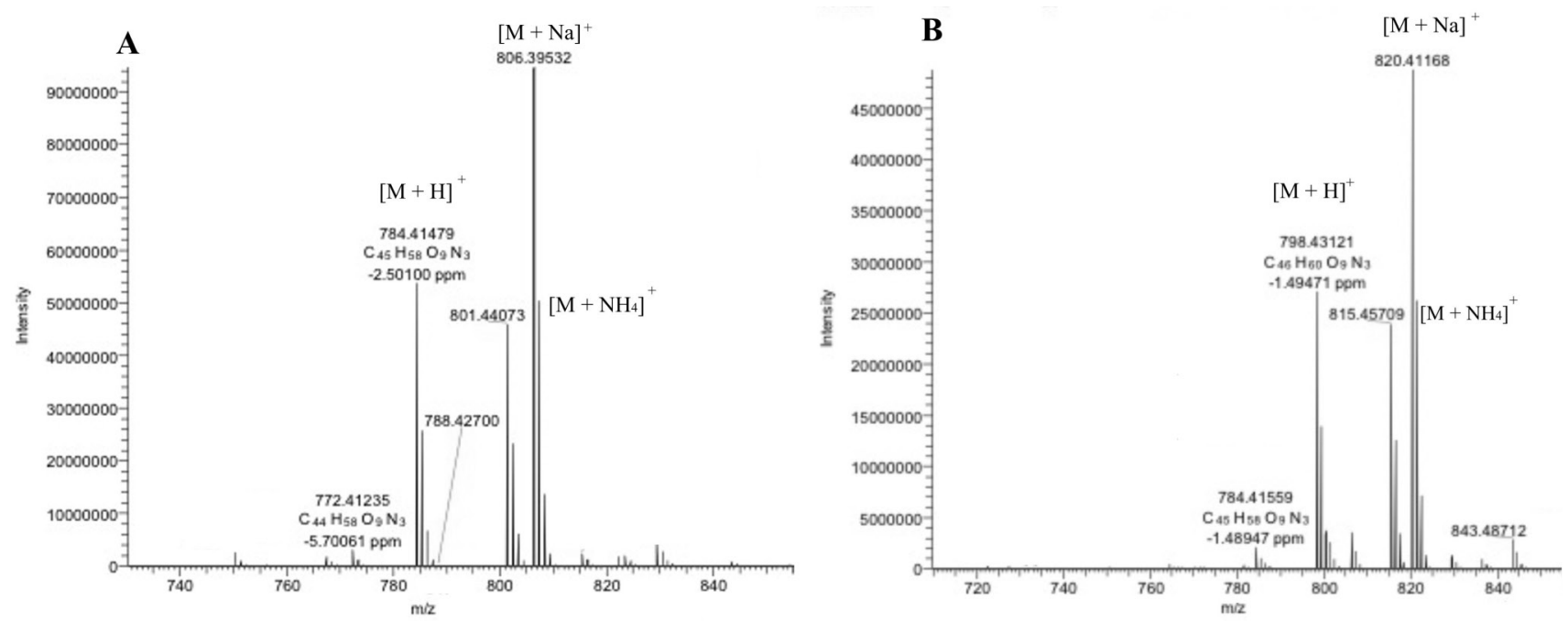

Figure 2. Full scan spectra of (A) beauvericin and (B) beauvericin A or F, produced by B. bassiana CG 71. Data acquired at ESI.

respectively. The $N$-methyl-L-phenylalanine (-161 Da) loss gave rise to the fragment ion $\mathrm{m} / \mathrm{z}$ 637.3486. While the peaks $m / z 555.3066$ and 294.1701 are detected due to the isopropylideneketene losses ( $82 \mathrm{Da}$ ), the ion $\mathrm{m} / \mathrm{z} 376.2121$ occurs through the rupture of the amide bond. It is worth to highlight that this new fragmentation proposal is fundamental for the confirmation of the beauvericin A or F presence in the organics extracts of entomopathogenic fungi.

The inspection of the MS/MS data showed that the peaks at $m / z, 523.2809$ in beauvericin and $m / z 682.4630$ in bassianolide spectra represent the loss of an 2-hydroxy- 3-methyl-1-buten-1-one molecule (100 Da), the identical D-HiV monomer (Figures 6 and 7). Additionally, the peaks at $m / z 623.3333$ (Figure 6) and 782.5159 (Figure 7) show the loss of $N$-methyl-L-phenylalanine $(-161 \mathrm{Da})$ and $N$-methyl-L-leucine $(-127 \mathrm{Da})$, respectively. Similar fragments containing phenylalanine residues $(\mathrm{m} / \mathrm{z} 262)$ are described for beauvericin and $\mathrm{E}$, which then lost $\mathrm{H}_{2} \mathrm{O}$ to give $m / z 244$ (Table 1).

Figure 8 shows fragmentation mechanism proposal for beauvericin $\mathrm{E}$ (precursor ion $\mathrm{m} / \mathrm{z}$ 736.4722). Differently from the mechanism of the other cyclodepsipeptides produced by the fungus, the MS/MS data from beauvericin E showed 


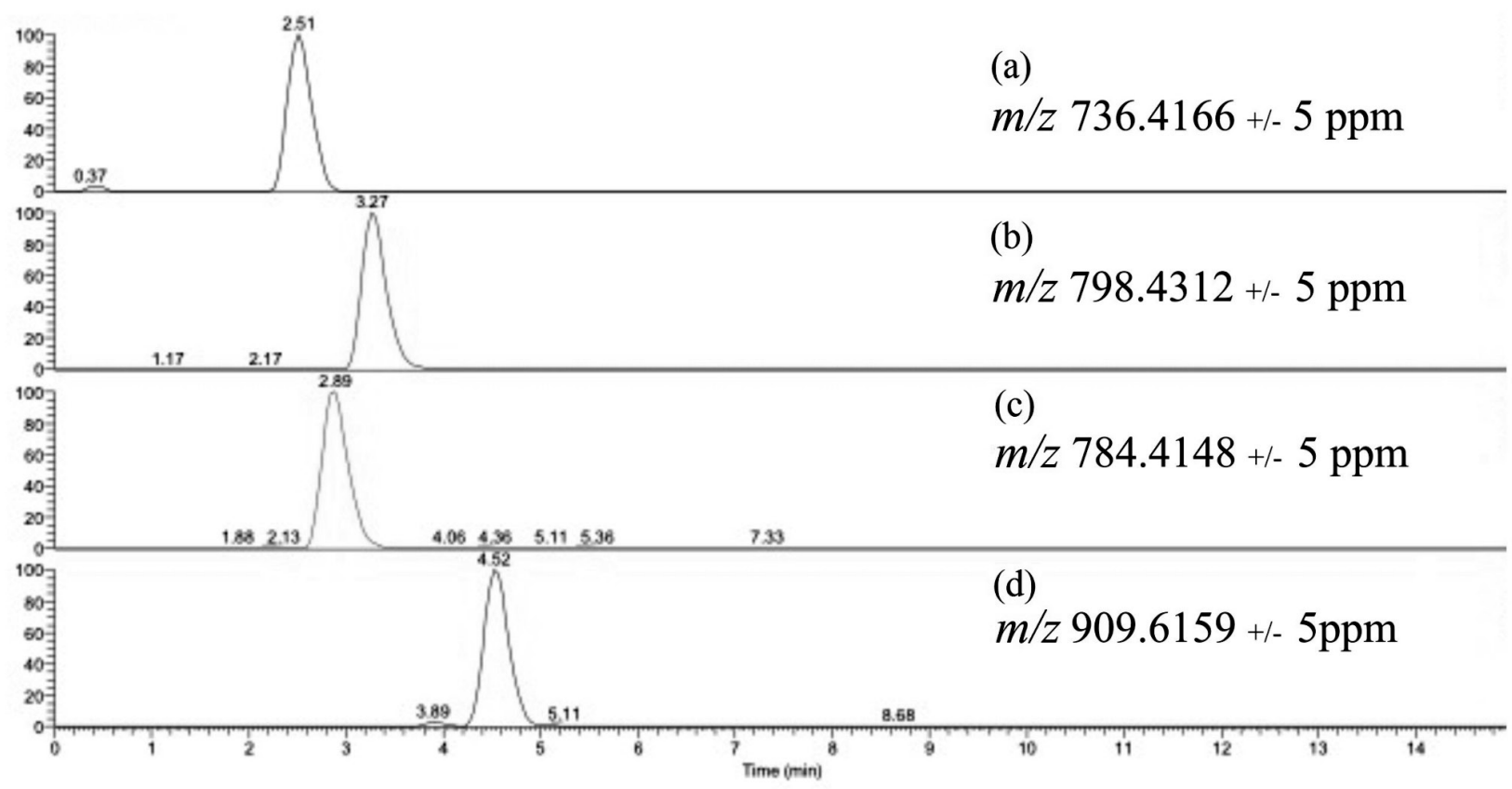

Figure 3. Selected ion chromatogram of (a) beauvericin E, (b) beauvericin A or F, (c) beauvericin and (d) bassianolide.

Table 1. Characterization (mass accuracy) of named ions cyclodepsipeptides and MS/MS parameters of Beauveria bassiana extracts

\begin{tabular}{|c|c|c|c|c|c|c|c|c|}
\hline & Beauvericin & Error / ppm & $\begin{array}{c}\text { Beauvericin A } \\
\text { or F }\end{array}$ & Error / ppm & Beauvericin $\mathrm{E}$ & Error / ppm & Bassianolide & Error / ppm \\
\hline Molecular formula & $\mathrm{C}_{45} \mathrm{H}_{57} \mathrm{~N}_{3} \mathrm{O}_{9}$ & & $\mathrm{C}_{46} \mathrm{H}_{59} \mathrm{~N}_{3} \mathrm{O}_{9}$ & & $\mathrm{C}_{41} \mathrm{H}_{57} \mathrm{~N}_{3} \mathrm{O}_{9}$ & & $\mathrm{C}_{48} \mathrm{H}_{84} \mathrm{~N}_{4} \mathrm{O}_{12}$ & \\
\hline Calcd. $[\mathrm{M}+\mathrm{H}]^{+}$ & 784.4175 & & 798.4332 & & 736.4175 & & 909.6168 & \\
\hline Calcd. $\left[\mathrm{M}+\mathrm{NH}_{4}\right]^{+}$ & 801.4441 & & 815.4598 & & 753.4441 & & 926.6433 & \\
\hline Calcd. $[\mathrm{M}+\mathrm{Na}]^{+}$ & 806.3996 & & 820.4153 & & 758.3996 & & 931.5988 & \\
\hline Found $[\mathrm{M}+\mathrm{H}]^{+}$ & 784.4148 & -2.50 & 798.4312 & -1.49 & 736.4166 & -0.26 & 909.6159 & -0.85 \\
\hline Found $\left[\mathrm{M}+\mathrm{NH}_{4}\right]^{+}$ & 801.4407 & & 815.4171 & & 753.4433 & & 926.6425 & \\
\hline Found $[\mathrm{M}+\mathrm{Na}]^{+}$ & 806.3953 & & 820.4117 & & 758.3986 & & 932.6007 & \\
\hline Precursor ion $(\mathrm{m} / \mathrm{z})$ & 784.4174 & 0.84 & 798.4323 & -0.12 & 736.4722 & & 909.6159 & -0.85 \\
\hline \multirow[t]{5}{*}{ Product ions $(\mathrm{m} / \mathrm{z})$} & 623.3333 & 1.09 & 637.3486 & 0.40 & 708.4216 & & 782.5159 & -1.25 \\
\hline & 523.2809 & 1.30 & 555.3066 & 0.29 & 575.3326 & & 682.4630 & 2.76 \\
\hline & 362.1967 & 1.42 & 376.2121 & 0.57 & 475.2802 & & 555.3640 & 3.37 \\
\hline & 262.1441 & 1.39 & 294.1701 & 0.51 & 362.1963 & & 427.3168 & -5.84 \\
\hline & $\begin{array}{l}244.1336 \\
\left(\mathrm{M}-\mathrm{H}_{2} \mathrm{O}\right)\end{array}$ & 1.45 & & & $\begin{array}{l}262.1438 \\
244.1332 \\
\left(\mathrm{M}-\mathrm{H}_{2} \mathrm{O}\right)\end{array}$ & & 328.2121 & -7.41 \\
\hline Collision energy / eV & 25 & & 25 & & & & 25 & \\
\hline Tube lens offset / V & 70 & & 70 & & & & 70 & \\
\hline
\end{tabular}

Calcd.: mass calculated.

CO loss, corresponding to the fragment ion $\mathrm{m} / \mathrm{z} 708.4216$ $[\mathrm{M}+\mathrm{H}-\mathrm{CO}]^{+}$. The other peaks $\mathrm{m} / \mathrm{z}, 575.3326,475.2802$, 362.1963 and 262.1438 occur due to the rupture of ester or amide bonds. The losses of $N$-(2-phenylethylidene)methanamine (-133 Da), 2-hydroxy-3-methyl-1-buten1-one (-100 Da), 2-amino-4-methyl-1-penten-1-one
(-113 Da) correspond to the peaks mentioned above. This fragmentation mechanism proposal evidences the presence of beauvericins $\mathrm{E}$ in the organic extracts of $B$. bassiana CG 71 and UNI 40 and may assist cyclodepsipeptide characterizations according to the additional structural information. 


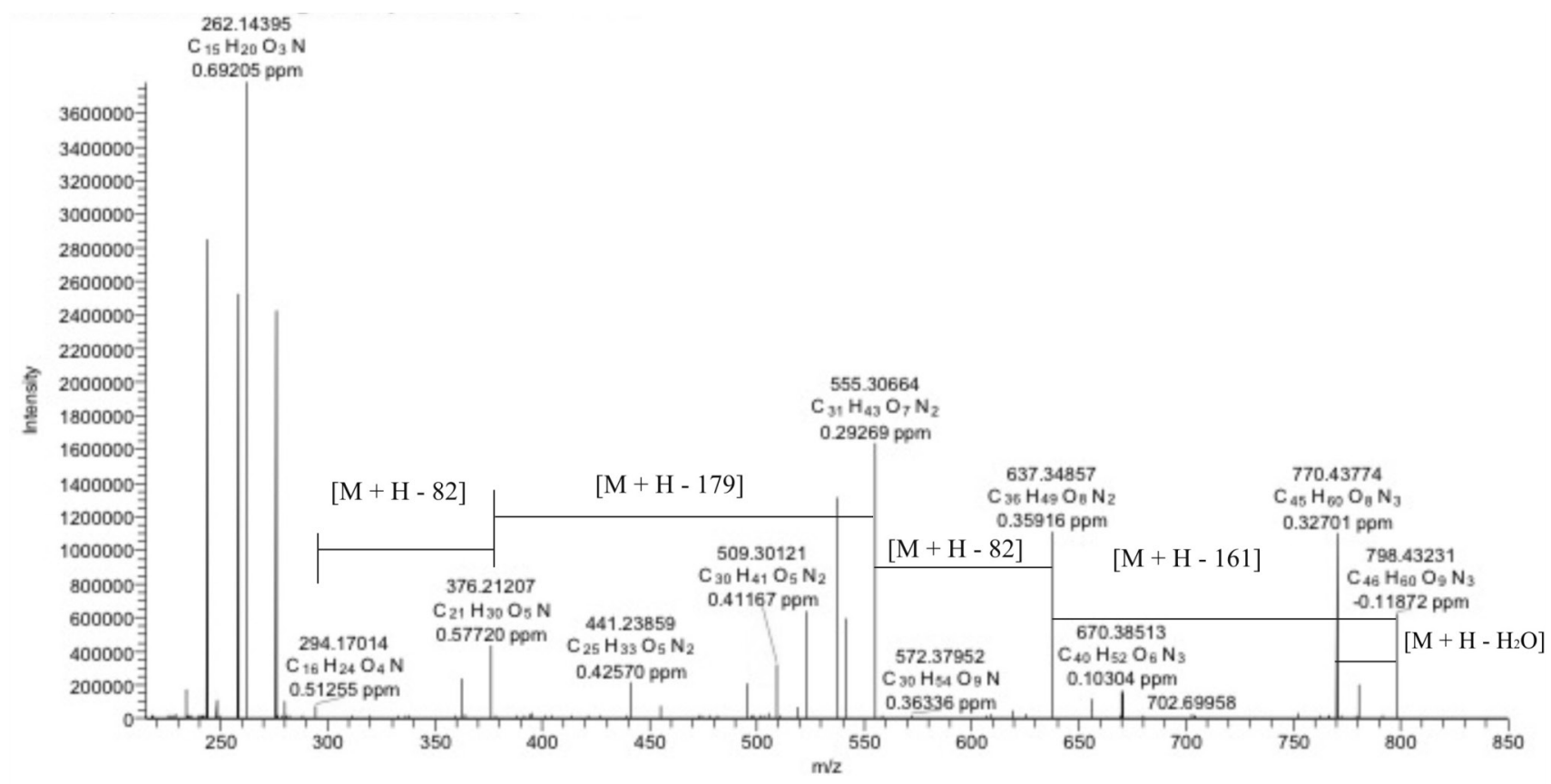

Figure 4. ESI-MS/MS spectra of beauvericin A or F, precursor ion $\mathrm{m} / \mathrm{z}, 798.4323$.

\section{Phylogenetic analyses}

Strains CG 71 and UNI 40 were grouped in a wellsupported clade with reference strains Beauveria bassiana in the phylogenetic analyzes conducted with partial RPB2 DNA sequences (Figure 9), thus confirming their identity.

\section{Larvicidal activity}

Table 2 shows larvicidal activity of the $B$. bassiana CG71 and UNI40 extracts against $3^{\text {rd }}$ instar of Aedes aegypti. The methanolic extract of strain CG71 revealed the highest activity with $\mathrm{LC}_{50}$ values of 0.9887 and $0.4653 \mathrm{ppm}$ after 24 and 48 hours, respectively. The ethyl acetate extract of CG71 displayed $\mathrm{LC}_{50}$ of 29.1777 and 1.2309 ppm after 24 and 48 hours, respectively.

The UNI 40 strain showed $\mathrm{LC}_{50}$ values of 0.7834 and $1.8149 \mathrm{ppm}$ for the ethyl acetate and methanolic extracts after 48 hours of incubation, respectively. These extracts showed no larvicidal activity in the first 24 hours of incubation. Besides the cyclodepsipeptides detected in both CG 71 and UNI 40 extracts, other peptides with peaks at $\mathrm{m} / \mathrm{z}$ above 1000 were detected in the ethyl acetate and methanolic extracts of UNI 40.

New studies using fungal organic extracts aim to identify new bioactive secondary metabolites, such as Fusarium sp. extract with trypanocidal activity, which revealed beauvericin as the responsible for the toxicity of Fusarium sp. to Trypanosoma cruzi. ${ }^{45}$
Beauvericin has been reported to be toxic on Aedes aegypti larvae with $\mathrm{LC}_{50} 26 \mathrm{ppm}^{24}$ and 10 and $20 \mu \mathrm{g} \mathrm{mL}^{-1}$ showed 39 and $86 \%$ of mortality in 48 hours, respectively. ${ }^{46}$ The presence of beauvericin, beauvericin $\mathrm{A}$ or $\mathrm{F}$, beauvericin $\mathrm{E}$ and bassianolide in the extracts of two B. bassiana strains may explain the excellent larvicidal activity observed.

The cyclodepsipeptides have shown insecticidal activity against several species, such as fifth instar larvae of the silkworm Bombyx mori, ${ }^{9}$ Calliphora erythrocephala, Aedes aegypti, Lygus spp., Spodoptera frugiperda, Schizaphis graminum ${ }^{47}$ and Sitophilus spp. ${ }^{48}$ However, the mycelium and conidia of a B. bassiana strain, pathogenic to Tribolium castaneum and Sitophilus oryzae, showed no toxicity against rats and mice. ${ }^{49}$

Bassianolide was described as a virulence factor of B. bassiana against Galleria mellonella, Spodoptera exigua, Helicoverpa zea $a^{50}$ and Atta sexdens sexdens..$^{51}$ Beauvericin was cytotoxic $\left(\mathrm{IC}_{50} 0.5 \mu \mathrm{M}\right)$ on a lepidopteran Spodoptera frugiperda (SF-9) cell line ${ }^{52}$ and on the Colorado potato beetle $\left(\mathrm{LC}_{50} 633 \mathrm{ppm}\right){ }^{15}$

\section{Conclusions}

The cyclodepsipeptides beauvericin, beauvericin A or $\mathrm{F}$, beauvericin $\mathrm{E}$ and bassianolide were identified in the $B$. bassiana CG71 and UNI 40 extracts. The methanolic extract of CG71, ethyl acetate and methanolic extracts of UNI40 showed larvicidal activity against $3^{\text {rd }}$ instar of Aedes aegypti with $\mathrm{LC}_{50}$ values of $0.4653,0.7834$ and $1.8149 \mathrm{ppm}$ after 48 hours of incubation, respectively. These results suggest 


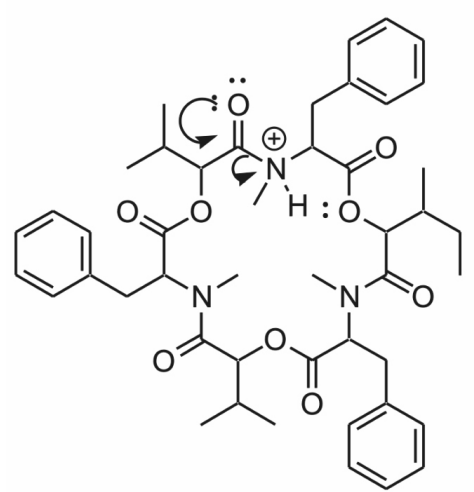

$m / z 798.4312$

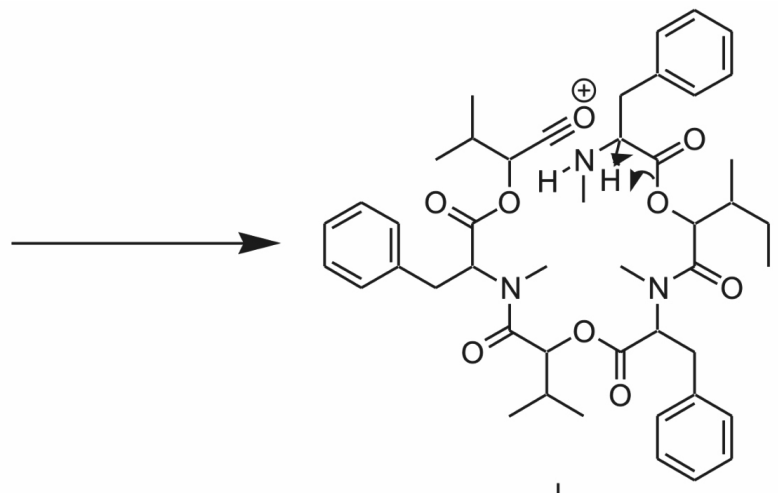<smiles>CNC(=C=O)Cc1ccccc1</smiles>
m/z 798.4312

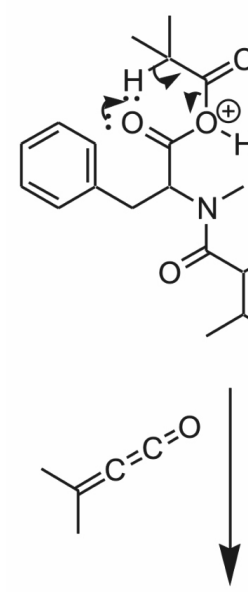<smiles>CCC(C)C(O)C(=O)N(C)C(Cc1ccccc1)C(=O)OC(C(=O)N(C)C(Cc1ccccc1)C(=O)OC1CCC1C(=O)O)C(C)C</smiles>

$m / z 637.3486$<smiles>CCC(C)C(O)C(=O)N(C)C(Cc1ccccc1)C(=O)OC(C(=O)N1CCCC1C(=O)O)C(C)C</smiles><smiles>CNC(Cc1ccccc1)C(=O)O</smiles><smiles>CCC(C)C(O)C(=O)N(C)C(Cc1ccccc1)C(=O)OC(C#N)C(=O)O</smiles><smiles>CCC(C)C(O)C(=O)N(C)C(Cc1ccccc1)C(=O)O</smiles>

$\mathrm{m} / \mathrm{z} 294.1701$

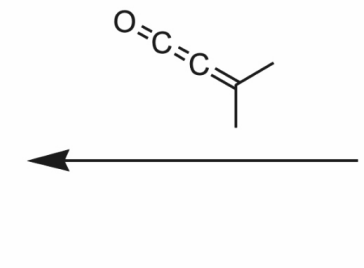

$m / z 376.2121$

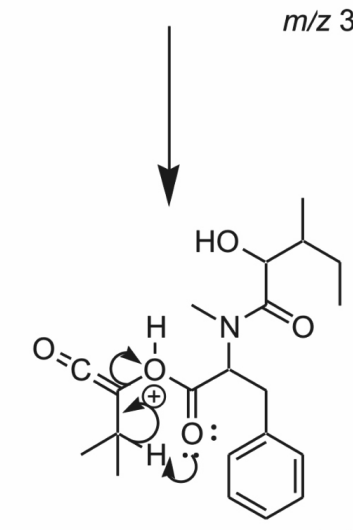

$\mathrm{m} / \mathrm{z} 376.2121$

Figure 5. Plausible fragmentation mechanism for beauvericin A or F in collision-induced dissociation (CID) spectra. 
<smiles>CC(C)C(Cc1ccccc1)OC(=O)C(OC(=O)C(Cc1ccccc1)N(C)C(=O)C(OC(=O)C(Cc1ccccc1)N(C)C(=O)C(Cc1ccccc1)N(C)C)C(=O)OC(C(=O)OC(C(C)C)C(C)C)C(C)C)C(C)C</smiles>

$m / z 784.4148$

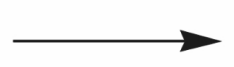<smiles>CNC(=C=O)Cc1ccccc1</smiles>

$m / z 784.4148$<smiles></smiles><smiles>CC(C)C(O)=C=O</smiles><smiles></smiles>

$m / z 623.3333$

Figure 6. Plausible fragmentation mechanism for beauvericin in collision-induced dissociation (CID) spectra.

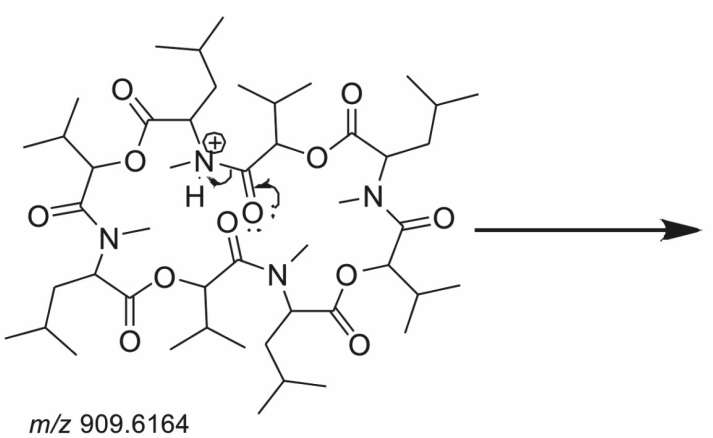

$m / z 909.6164$<smiles>C#CC(OC(=O)C(CC(C)C)N(C)C(=O)C(OC(=O)C(CC(C)C)N(C)C(C(C)C)C(OC(=O)C(CC(C)C)NC)C(=O)O)C(C)C)C(C)C</smiles>

$m / z 682.4630$

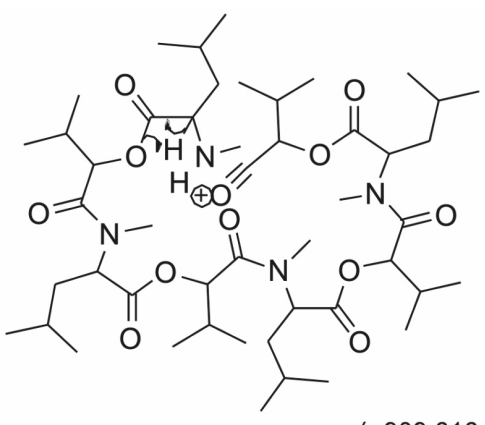<smiles>CNC(=C=O)CC(C)C</smiles><smiles>CCCCCCCCC(=O)C(C)C</smiles><smiles></smiles>

Figure 7. Plausible fragmentation mechanism for bassianolide in collision-induced dissociation (CID) spectra. 


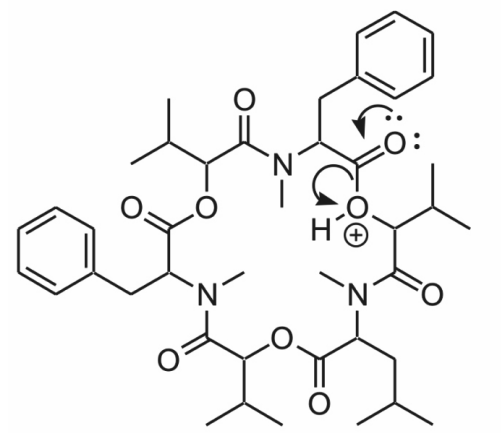

$m / z 736.4166$<smiles></smiles>

m/z 575.3326<smiles>CCCCCCCCCC(C)C</smiles><smiles>CC(C)C[C@H](C)N(C)C(=O)OC(C(=O)N(C)C(Cc1ccccc1)C(=O)OC(C#[O+])C(C)C)C(C)C</smiles>

$m / z 475.2802$<smiles>CC(C)CC(C(=O)OC(C(=O)N(C)C(=O)C(O)C(C)C)C(=O)N(C)C(Cc1ccccc1)C(=O)OC(C(=O)N(C)C(=O)C(O)C(C)C)C(C)C)N(C)C(=O)C(Cc1ccccc1)C(C)C</smiles>

$m / z 736.4166$<smiles>CN=CCc1ccccc1</smiles>

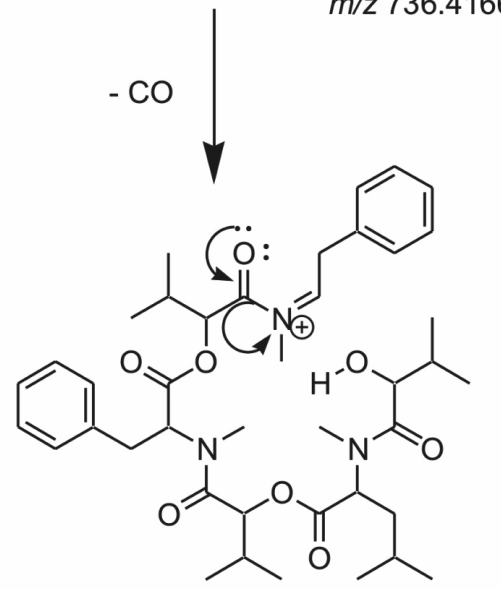

$m / z 708.4216$

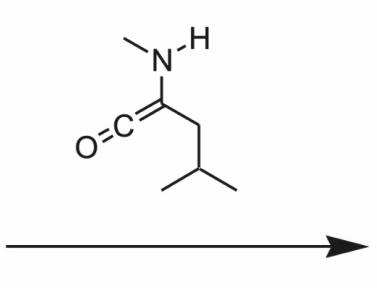<smiles>CCCCCCCCCCC(C)C(O)C(=O)CC</smiles>

$m / z 362.1963$<smiles>CNC(Cc1ccccc1)C(=O)OC(C#[O+])C(C)C</smiles>

m/z 262.1332 
Table 2. Larvicidal activity Beauveria bassiana UNI40 and CG71 extracts against $3^{\text {rd }}$ instar of Aedes aegypti

\begin{tabular}{lcccc}
\hline Extract & $\mathrm{LC}_{50}(24$ hours $) / \mathrm{ppm}$ & $95 \% \mathrm{CI}$ & $\mathrm{LC}_{50}$ (48 hours) / ppm & $95 \% \mathrm{CI}$ \\
\hline CG71a & 29.1777 & $24.2879-35.5307$ & 1.2309 & $1.1736-1.2950$ \\
CG71m & 0.9887 & $0.9710-1.0076$ & 0.4653 & $0.4650-0.4656$ \\
UNI401a & no activity & & 0.7834 & $0.7460-0.8251$ \\
UNI401m & no activity & 1.8149 & $1.7527-1.8906$ \\
\hline
\end{tabular}

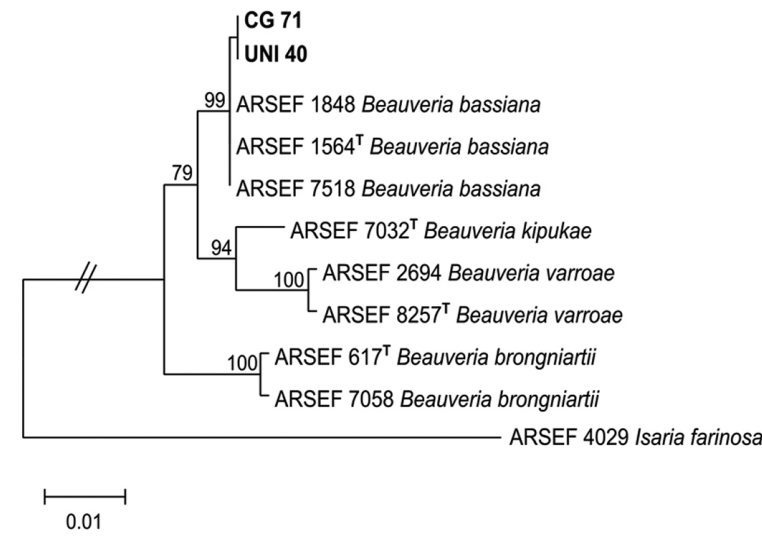

Figure 9. Maximum likelihood phylogenetic tree of partial RPB2 sequences of CG 71 and UNI 40, and reference strains of Beauveria bassiana and related species. Bootstrap values equal or higher than $70 \%$ are showed by the nodes. Isaria farinosa (ARSEF 4029) was used as the outgroup. T identifies ex-type strains.

that cyclodepsipeptides are probably the active principles responsible for the larvicidal action. Therefore, further studies must be undertaken in order to isolate and confirm the compounds responsible for this activity. Therefore, they may be considered as potential insecticidal components in the formulations for the Dengue and Zika vector. The liquid chromatography coupled with electrospray ionization tandem mass spectrometry (LC-ESI-MS/MS) methodology used proved to be an excellent tool for the identification of cyclodepsipeptides in fungal extracts, and contributed with new fragmentation studies for beauvericin $\mathrm{A}$ or $\mathrm{F}$ and $\mathrm{E}$.

\section{Acknowledgments}

The authors would like to thank Dr Luis Francisco Angeli Alves and Prof Dr Pedro Manuel Oliveira Janeiro Neves for the fungal strains, and Prof Dr Ludwig H. Pfenning for infrastructure of DNA analyses. The authors thank the financial support from International Foundation of Science (IFS, grant 2010/F/4898-1) and DIRPPG (Diretoria de Pesquisa e Pós-Graduação of Universidade Tecnológica Federal do Paraná, Londrina Campus), Conselho Nacional de Desenvolvimento Científico e Tecnológico (CNPq) and Fundação Araucária for scholarships.

\section{References}

1. Clarkson, J. M.; Charnley, A. K.; Trends Microbiol. 1996, 4, 197.

2. Khachatourians, G. G.; J. Invertebr. Pathol. 1992, 59, 212.

3. Goettel, M. S.; Eilenberg, J.; Glare, T. R. In Comprehensive Molecular Insect Science; Gilbert, L. I.; Iatrou, K.; Gill, S., eds.; Elsevier: Boston, 2005, p. 361.

4. Leathers, T. D.; Gupta, S. C.; Alexander, N. J.; J. Ind. Microbiol. 1993, 12, 69.

5. De La Rosa, W.; Alatorre, R.; Barrera, J. F.; Toreillo, C.; J. Econ. Entomol. 2000, 93, 1409.

6. Leger, St. R. J.; Charnley, A. K.; Cooper, R. M.; J. Invertebr. Pathol. 1986, 48, 85.

7. Von Döhren, H.; Adv. Biochem. Eng./Biotechnol. 2004, 88, 217.

8. Hamill, R. L.; Higgens, C. E.; Boaz, H. E.; Gorman, M.; Tetrahedron Lett. 1969, 49, 4255.

9. Suzuki, A.; Kanaoka, M.; Isogai, A.; Murakoshi, S.; Ichinoe, M.; Tamura, S.; Tetrahedron Lett. 1977, 25, 2167.

10. Kuzma, M.; Jegorov, A.; Kačer, P.; Havlíček, V.; J. Mass Spectrom. 2001, 36, 1108.

11. McInnes, A. G.; Smith, D. G.; Wat, C. K.; Vining, L. C.; Wright, J. L. C.; J. Chem. Soc., Chem. Commun. 1974, 8, 281.

12. Takahashi, S.; Kakinuma, N.; Uchida, K.; Hashimoto, R.; Yanagisawa, T.; Nakagawa, A.; J. Antibiot. 1998, 51, 596.

13. Vining, L. C.; Kelleher, W. J.; Schwarting, A. E.; Can. J. Microbiol. 1962, 8, 931.

14. Quesada-Moraga, E.; Vey, A.; Mycol. Res. 2004, 108, 441.

15. Roberts, D. W.; Gupta, S.; Leger, R. J. St.; Pesq. Agropec. Bras. 1992, 27, 325.

16. Qinggui, W.; Lijian, X.; Molecules 2012, 17, 2367.

17. Isaka, M.; Kittakoop, P.; Kirtikara, K.; Hywel-Jones, N. L.; Thebtaranonth, Y.; Acc. Chem. Res. 2005, 38, 813.

18. Xu, Y.; Orozco, R.; Wijeratne, E. M. K.; Gunatilaka, A. A. L.; Stock, S. P.; Molnár, I.; Chem. Biol. 2008, 15, 898.

19. Toman, E.; Makrlík, E.; Vaňura, P.; Monatsh. Chem. 2011, 142, 779.

20. Waetjen, W.; Debbab, A.; Hohlfeld, A.; Chovolou, Y.; Proksch, P.; Toxicol. Lett. 2014, 231, 9.

21. Wu, Y.; Huang, X.; Deng, J.; J. Beijing Norm. Univ., Nat. Sci. 1999, 35, 114. 
22. Gupta, S.; Krasnoff, S. B.; Underwood, N. L.; Renwick, J. A. A.; Roberts, D. W.; Mycopathologia 1991, 115, 185.

23. Castlebury, L. A.; Sutherland, J. B.; Tanner, L. A.; Henderson, A. L.; Cerniglia, C. E.; World J. Microbiol. Biotechnol. 1999, $15,119$.

24. Gupta, S.; Montllor, C.; Wang, Y. S.; J. Nat. Prod. 1995, 58, 733.

25. Fukuda, T.; Arai, M.; Tomoda, H.; Omura, S.; J. Antibiot. 2004, $57,117$.

26. WHO; Comprehensive Guidelines for Prevention and Control of Dengue and Dengue Hemorrhagic Fever; World Health Organization, Regional Office for South-East Asia, 2011, p. 1.

27. Bhatt, S.; Gething, P. W.; Brady, O. J.; Messina, J. P.; Farlow, A. W.; Moyes, C. L.; Drake, J. M.; Brownstein, J. S.; Hoen, A. G.; Sankoh, O.; Myers, M. F.; George, D. B.; Jaenisch, T.; Wint, G. R. W.; Simmons, C. P.; Scott, T. W.; Farrar, J. J.; Hay, S. I.; Nature 2013, 496, 504.

28. Linss, J. G. B.; Brito, L. P.; Garcia, G. A.; Araki, A. S.; Bruno, R. V.; Lima, J. B. P.; Valle, D.; Martins, A. J.; Parasites Vectors 2014, 7, 25.

29. Imperato, P. J.; J. Community Health 2016, 41, 674.

30. Oliveira, W. K.; Cortez-Escalante, J.; De Oliveira, W. T. G. H.; Carmo, G. M. I.; Henriques, C. M. P.; Coelho, G. E.; França, G. V. A.; Morb. Mortal Wkly. Rep. 2016, 65, 242.

31. Santoro, P. H.; Neves, P. M. O. J.; Alexandre, T. M.; Sartori, D.; Alves, L. F. A.; Fungaro, M. H. P.; J. Invertebr. Pathol. 2008, $97,83$.

32. Domsch, K. H.; Gams, W.; Anderson, T. H.; Compendium of Soil Fungi, $2^{\text {nd }}$ ed.; IHW-Verlag: Eching, Germany, 2007.

33. Liu, Y. J.; Whelen, S.; Hall, B. D.; Mol. Biol. Evol. 1999, 16, 1799.

34. Rehner, S. A.; Minnis, A. M.; Sung, G. H.; Luangsa-ard, J. J.; Devotto, L.; Humber, R. A.; Mycologia 2011, 103, 1055.

35. Tamura, K.; Stecher, G.; Peterson, D.; Filipski, A.; Kumar, S.; Mol. Biol. Evol. 2013, 30, 2725.

36. Darriba, D.; Taboada, G. L.; Doallo, R.; Posada, D.; Nat. Methods 2012, 9, 772.

37. Bunyapaiboonsri, T.; Yoiprommarat, S.; Srisanoh, U.; Choowong, W.; Tasanathai, K.; Hywel-Jones, N. L.; Luangsaard, J. J.; Isaka, M.; Phytochem. Lett. 2011, 4, 283.
38. Wulfson, N. S.; Puchkov, V. A.; Rozinov, B. V.; Zyakoon, A. M.; Shemyakin, M. M.; Ovchinnikov, Y. A.; Kiryushkin, A. A.; Ivanov, V. T.; Tetrahedron Lett. 1965, 32, 2793.

39. Daniel, J. F. S.; Filho, E. R.; Nat. Prod. Rep. 2007, 24, 1128.

40. Herebian, D.; Zühlke, S.; Lamshöft, M.; Spiteller, M.; J. Sep. Sci. 2009, 32, 939.

41. Song, H. H.; Lee, H. S.; Lee, G. P.; Ha, S. D.; Lee, C.; Food Addit. Contam., Part A 2009, 26, 518.

42. Gonzalezi, D. J.; Xu, Y.; Yang, Y. L.; Esquenazia, E.; Liu, W. T.; Edlund, A.; Duong, T.; Du, L.; Molnár, I.; Gerwick, W. H.; Jensen, P. R.; Fischbach, M.; Liaw, C. C.; Straight, P.; Nizet, V.; Dorrestein, P. C.; J. Proteomics 2012, 75, 5069.

43. Devreese, M.; De Baere, S.; De Backer, P.; Croubels, S.; Talanta 2013, 106, 212.

44. El-Elimat, T.; Figueroa, M.; Ehrmann, B. M.; Cech, N. B.; Pearce, C. J.; Oberlies, N. H.; J. Nat. Prod. 2013, 76, 1709.

45. Campos, F. F.; Junior, P. A. S.; Romanha, A. J.; Araújo, M. S. S.; Siqueira, E. P.; Resende, J. M.; Alves, T. M. A.; MartinsFilho, O. A.; Santos, V. L.; Rosa, C. A.; Zani, C. L.; Cota, B. B.; Mem. Inst. Oswaldo Cruz 2015, 110, 65.

46. Grove, J. F.; Pople, M.; Mycopathologia 1980, 70, 103.

47. Wang, Q.; Xu, L.; Molecules 2012, 17, 2367.

48. Langenfeld, A.; Blond, A.; Gueye, S.; Herson, P.; Nay, B.; Dupont, J.; Prado, S.; J. Nat. Prod. 2011, 74, 825.

49. Dal Bello, G. M.; Padin, S. B.; Cagliada, P.; Carbone, C.; Vasicek, A.; Arcas, J.; Rev. Toxicol. 2000, 17, 36.

50. Xu, Y.; Orozco, R.; Wijeratne, E. M. K.; Espinosa-Artiles, P.; Gunatilaka, A. A. L.; Stock, S. P.; Molnár, I.; Fungal Genet. Biol. 2009, 46, 353.

51. Loureiro, E. S.; Monteiro, A. C.; Arq. Inst. Biol. 2004, 71, 35.

52. Fornelli, F.; Minervini, F.; Logrieco, A.; J. Invertebr. Pathol. 2004, 85, 74 .

Submitted: May 12, 2016

Published online: September 9, 2016

FAPESP has sponsored the publication of this article. 